\title{
The pedagogical aspects of using multimedia presentations in the classroom - case study Serbia
}

\author{
Ivan Tasić ${ }^{1}$ \\ Department of methodology of science and technology in education, \\ Technical Faculty Mihajlo Pupin, \\ University of Novi Sad, Zrenjanin, Serbia

\section{Dragana Glušac} \\ Department of methodology of science and technology in education, \\ Technical Faculty Mihajlo Pupin, \\ University of Novi Sad, Zrenjanin, Serbia

\section{Dijana Karuović} \\ Department of methodology of science and technology in education, \\ Technical Faculty Mihajlo Pupin, \\ University of Novi Sad, Zrenjanin, Serbia
}

\begin{abstract}
In the last ten years we have witnessed significant progress within the Serbian education system when it comes to identifying strategies that are closer to European standards. The aim of this paper was to establish the pedagogical aspects of using multimedia presentations in the classroom in Serbia, as well as the factors that influence possible differences in teachers' views regarding the implementation of multimedia presentations in teaching. The factors that impact and distinguish teacher attitudes were examined within the context of the overall effectiveness of using multimedia presentations as it affects overall student achievement. We took into account the level of training among teachers, their subject or discipline, teacher age and gender. Conclusions are oriented towards training teachers in this area.
\end{abstract}

Keywords: multimedia presentation, motivation, effectiveness, teacher education.

1 tasici@tfzr.uns.ac.rs 


\section{Introduction}

The primary motivation for this research proceeded from the fact that the Serbian education system has faced technological challenges for the last two decades, as has Serbian society as a whole. Serbian students have largely adopted modern information communication technology (ICT) in their everyday lives. Teachers have been changing their ways of working in schools and trying to adapt to technological developments. The traditional way of working is going through shifts imposed by digital technologies.

The specific aim was to obtain more profound insight, which is currently lacking, into teaching practice in the area of multimedia presentations in the teaching process, their design and application, as well as teachers' views on the effects of implementation in the classroom.

The theoretical research framework is presented in the first part of the paper. The theoretical parts elaborate on previous studies regarding: pedagogical changes and acceptance of technology in the classroom, the effectiveness of using multimedia presentations in teaching, and teachers' attitudes regarding the implementation of multimedia in teaching.

The second part of the paper describes empirical research conducted by examining the opinions of 368 teachers, in which common practices in the area of preparing multimedia presentations, as well as diversity, will be influenced by attitudes regarding their effectiveness. The general impression is that the most common and typical form of computer use in teaching in schools in Serbia is the digital presentation. The use of such presentations in the classroom has become a common practice in Serbian schools. This work researches how and to what extent teachers create presentations, and how they use them in the classroom. A conclusion regarding the existence of a statistically significant correlation between dimensions related to the level of training among teachers, subject or discipline, age and gender, as well as their different views on the effectiveness of using presentations in the classroom, will be demonstrated by means of correlation methods. The conclusions are significant, because they indicate the level of necessity for effective methods of implementation, for preparing good presentations, and for use in the teaching process with the goal of improving educational achievements. The academic contribution of the research should anticipate the adoption of a strategy for creating an institutional framework for ICT integration into teaching methods. This includes the need to develop skills on the part of teachers for creating and adequately implementing high-quality presentations in the teaching process. Also, this study moves in the direction of the idea to create a repository of presentations for individual subjects, which would be available on the 'cloud' for any teacher, thereby increasing the level of use as well as reducing possible errors, and significantly increasing the efficiency of teaching.

Special emphasis in the research will be devoted to the issue of professional competence among teachers, as it may suggest specific measures for improving the system. The extent to which teachers acquire multimedia competencies in the course of their formal education, and to what extent they are left to themselves to cope in the course of lifelong learning, is a question that is crucial to this topic. From profession to profession, and from faculty to faculty, the situation is different. Formal teacher education, according to 
Chien et al. (2012), requires the transformation of pre-service science teacher roles over the course of the teacher's education - shifting pre-service teachers from roles involving the passive use of technology, as they themselves learn technology integration, into active designers of technology. Existing programmes of formal teacher education facilitate the pre-service teacher's critical re-examination of the affordances of technology for their teaching practices, from the aspects of subject matter selection, motivation empowerment, information presentation, activity design, and pedagogy transition.

\section{Theoretical Background - Pedagogical Changes and Accepting Technology in the Classroom}

Le Fevre (2014) tried to better understand why professional learning initiatives intended to bring about changes in teaching practices often fail. He defined changes in teaching as involving a certain degree of risk-taking, and asserted that if the level of risk is perceived to be too high, teachers will not engage in the pedagogical practices promoted. Therefore he recommends reducing the level of perceived risk, and providing a supportive environment in which teachers feel empowered to take risks.

The process of integrating new methods in the classroom represents an innovation in teaching for students, but also and to a much greater extent a barrier for working teachers, school principals, trainers, coaches, administrators, technical and support staff, and so for entire educational institutions. Students who are currently in elementary, high school, and college are often termed the 'digital generation'. They were born after the information revolution. They grew up, acquired habits, knowledge, skills, and built attitudes in an era of rapid multimedia and non-linear information, 3D interfaces, touchscreen displays, virtual reality environments and parallel worlds. It can be said that teachers are 'guests' in their era, and they find it much harder to adapt. There is a term in literature to describe those born before the 1980s; they are 'digital immigrants' while those born in or after 1980 are 'digital natives' (Prensky, 2001, cited in Kwei Wang et al, 2014 a). Bennett (2010) states that current education systems cannot cater for 'digital natives', i.e. students born in the IT era. Classes limited to benches, walls and a frontal position for teachers are far removed from what children find interesting and where they can find a motivational trigger for work in lessons, and this leads to a gradual alienation from school and from understanding the value of the right kind of learning and knowledge.

Embracing technology entails changes for teachers on several levels (Ertmer \& Ottenbreit-Leftwich, 2010): changes in beliefs, attitudes, or pedagogical ideologies; content knowledge; pedagogical knowledge of instructional practices, strategies, methods, or approaches; and novel or altered instructional resources, technology, or materials. It is therefore possible to speak of an evolution of the teaching profession. Teo (2009) detected the variables that directly affect the level of technology acceptance among teachers: perceived usefulness, attitude towards computer use, and computer self-efficacy, while perceived ease of use, technological complexity, and facilitating conditions affect technology acceptance indirectly. 
Therefore, we can conclude that the application of multimedia presentations in teaching can be referred to as the first step in accepting multimedia in educational reality. In the first cycle of acceptance, multimedia presentations are, due to their characteristics, a very prevalent form of electronic support in the classroom. The reason is primarily the possibility of combining different media (Lachs, 2013). According to Prabhakaran (2000), multimedia presentations comprise various media objects, such as text, audio, image, and video, which are delivered to users according to certain temporal relationships. In stored multimedia presentations, these temporal relationships are explicitly formulated by the author(s) and stored along with the presentations. Authors and researchers in this field agree on the issue of the enormous popularity of multimedia presentations in the classroom. According to Craig and Amernic (2006), in the past three decades there has been a decisive shift in the media used to communicate messages in educational settings. "We have gone from the era of 'chalk and talk', and occasional flip charts to overhead transparencies and PowerPoint slides." PowerPoint is one of the most frequently used tools to present multimedia for educational purposes (Reus et al., 2008). Multimedia teaching has advantages with which the traditional teaching model cannot compare. With multimedia teaching, eyes are looking, ears listening, mouths speaking, hands writing, brains bringing all of this together; students will greatly improve their passion for learning, leading to higher class efficiency (Li, 2009).

Another question is important for the research in this paper: the ability and willingness of teachers to prepare multimedia materials in a pedagogically appropriate manner, adapted to the age and aspirations of the pupils that use them. This issue of the appropriateness of multimedia applications for certain types of training is underlined by Atkins (1993) as the first of several major issues. Apart from this issue, it points to the type of tutoring support to be provided to the learner and the role of the traditional teacher in relation to it.

Is there a psychological justification for using digital presentations in teaching? Liang (2010) believes that the presentation of instructional information in the classroom must take into consideration learners' needs and their cognitive features. PowerPoint can enhance teaching sessions by providing a roadmap, reinforcing what the teacher says and allowing the use of graphics and other multimedia channels to clarify understanding and support different learning styles (Hashemi et al., 2012). Psychologists have also dealt with the phenomenon of multimedia presentations. For example, Berk (2011) in his study believes that multimedia learning promotes acquisition, retention, and transfer (the application) of information. His analysis of the empirical findings of research over the past half-century highlights the effectiveness of multimedia classes or modules. He states that, according to Kirschner et al. (2011), multimedia auditory/verbal and visual/pictorial stimuli increase comprehension, memory, and a deeper learning, that is, they are more effective than any single stimulus on its own. In addition to this, there is an interesting study by Yang et al. (2013) in which they researched university learners' visual attention during a PowerPoint (PPT) presentation in a real classroom, measuring eye movement indicators. Teachers gave the presentation to students whose eye movements were recorded by an eye tracking system. The total time spent on interest zones was abstracted to indicate 
their visual attention. The average duration of fixation, indicating the average information processing time, was longer for the picture zones.

Mayer (2001) elaborates on the topic of multimedia while dealing with the problem of perceptive power among students, in terms of burdening the audio and visual channels. If a multimedia presentation is created so that the textual information is supplied via a longer written text, and the slide is enriched by multimedia elements, an image, animation, etc., then the visual senses are burdened by processing more information at once, and the audio channel remains unused. Therefore, researchers suggest breaking learning content into small successive segments to reduce cognitive demands (Mayer, 2001; Paas \& Merrienboer, 1994 cited in Chuang \& Liu, 2012).

\section{Research Goals and Hypotheses}

The research problem regards access to, and efficient use of presentations in school teaching in Serbia, while the research priority concerns the factors that impact the possible differences in teachers' views on implementing multimedia presentations in teaching.

The entire study is aimed at solving this problem, i.e. providing answers to the question: what attitudes exist among teachers regarding the effectiveness of applying multimedia presentations in classes, with student achievements in mind. At the same time, answers to additional questions will be sought: whether there is a correlation between teacher age, gender, training in the field of applying ICT, or a certain affiliation between technology and the subjects taught, on the one hand, and significantly different views regarding the effectiveness of application in the teaching process, on the other.

Do different attitudes exist among teachers in schools in Serbia, in terms of the extent to which they accept technology and its use in the classroom? Are there factors that might allow us to differentiate between teachers with regard to the current question, and what are they? Teachers need a good deal of time to create a multimedia presentation (Sikos, 2009). The question is whether, owing to the time they regularly spend preparing and teaching or engaging in supplementary or additional activities and administrative tasks, teachers already have too many responsibilities to spend time producing high quality, functional presentations. Do teachers of different types of subjects and from various disciplines differ in terms of viewing multimedia presentations as an effective teaching resource? Is the type of teacher training for the implementation of ICT in the classroom, and for making high quality and efficient presentations, a determining factor? Is it age? Does scientific discipline play a part? Or gender? Concrete answers to these questions were sought.

Based on the above considerations, the following hypotheses were put forward in this paper:

$\mathrm{H} 1$ : The importance of teachers' views on the effectiveness of multimedia presentations in improving student achievement varies depending on the type of subject taught.

$\mathrm{H} 2$ : The importance of teachers' views on the effectiveness of multimedia presentations in improving student achievement varies depending on teachers' training in applying ICT in teaching. 
H3: The importance of teachers' views on the effectiveness of multimedia presentations means that overall student achievement varies depending on teacher age. $\mathrm{H} 4$ : The importance of teachers' views on the effectiveness of multimedia presentations means that overall student achievement varies depending on teacher gender.

\section{Methodology}

\section{Survey Instruments}

Data collection was achieved by means of the quantitative method through both online and paper questionnaires, the latter for the convenience of teachers who may have difficulty using the internet or choose not to use it often. The questionnaire cosisted of 41 questions. The research was transversal, i.e. a focus group at a particular moment was covered by the research. The sample consisted of teachers in primary, secondary vocational, and grammar schools in Serbia, who teach subjects that are divided into five groups: natural sciences, social sciences, technical and technological sciences, arts, and physical education. A random sample for the study was chosen among all elementary schools and three-year and four-year secondary schools across Serbia. In that way, a representative sample was obtained for the population of teachers who teach in elementary schools, grammar schools, four-year and three-year vocational schools in Serbia. The focus was on including teachers based on their gender, age, type of school, and teaching field (natural, technical, social sciences and art). The study is empirical because empirical data was gathered systematically, so as to verify the research hypothesis that teachers of different subjects have significantly different views on the effectiveness of applying these teaching resources, and that this affects overall student achievement. The 379 questionnaires from the representative focus sample were processed, and 368 accepted.

The first part of the questionnaire contains questions regarding potential primary influencing factors in teacher attitudes: teacher age, training, the field the teacher's subject belongs to, and gender.

Table 1

Survey Structure

\begin{tabular}{lll}
\hline Main/Basic Factors & Tag & Index \\
\hline Teacher Age & $\mathrm{AT}_{\mathrm{i}}$ & $\mathrm{i}=1$ \\
Teacher Training & $\mathrm{TE}_{\mathrm{i}}$ & $\mathrm{i}=1-2$ \\
Discipline & $\mathrm{SD}_{\mathrm{i}}$ & $\mathrm{i}=1-5$ \\
Gender & $\mathrm{G}_{\mathrm{i}}$ & $\mathrm{i}=1-2$ \\
\hline Group of Questions - variables & $\mathrm{Tag}_{\mathrm{i}}$ & Index \\
\hline Pedagogical Questions & $\mathrm{PQ}_{\mathrm{i}}$ & $\mathrm{i}=1-10$ \\
MMP Preparation Practices & $\mathrm{DMP}_{\mathrm{i}}$ & $\mathrm{i}=1-18$ \\
Teachers' Views on the Effectiveness of Using MMP & $\mathrm{EMP}_{\mathrm{i}}$ & $\mathrm{i}=1-10$ \\
\hline
\end{tabular}


The second part of the questionnaire contains three groups of questions. The first relates to pedagogical issues, analysing implementation in teaching. The second includes questions regarding teacher practices when preparing presentations. We asked a number of detailed questions to help us understand their customary practices, which they indicated by choosing one of several options. A third group of questions relates to the issues of efficiency in teaching (EMP), when supported by multimedia presentations. These questions were of the closed type and were combined with five-point Likert scales with choices ranging from 'I strongly disagree' to 'I completely agree'.

The analysis will be presented in two parts: the descriptive and the correlational. Data processing involved descriptive statistics and correlation analysis that enable a rational description of teacher practice in the design and implementation of multimedia presentations in the classroom, which is the subject of this research. For hypothesis testing, correlation analysis was used in order to reveal the direction and level of relation for variables: age, teacher education, and the subject taught, as well as attitudes regarding the overall achievements of students when multimedia presentations are used.

\section{Participants and Data Collection}

379 respondents participated in the sample, of which 368 completed the questionnaire correctly. Among them were 255 women and 113 men. Such a proportionally small number of men in the sample is a consequence of the employment structure of teachers in Serbia. According to the Statistical Office of the Republic of Serbia (2011), of those employed in education $67 \%$ are women and $33 \%$ men. If we look at elementary schools specifically the percentage of women is even higher than in secondary schools and higher education.

The sample was divided according to four criteria.

According to the first criterion (K1), namely, the disciplines that the subjects taught by the teachers belong to, the sample was divided into five groups: natural sciences, social sciences, technical and technological sciences, art subjects, and physical education.

According to the second criterion (K2), the sample was divided into two groups: teachers who acquired competencies for ICT and multimedia application in teaching through formal education ( $\mathrm{g} 1$ ), and teachers who had acquired them through professional training programmes (g2).

According to the third criterion (K3), teacher age, respondents were divided into 5 groups: teachers aged 20-30, 31-40, 41-50, 51-60, and those over 60 years old.

Sample division according to the fourth criterion (K4) is based on gender. Respondents were divided into 2 groups: male and female.

\section{Results}

Table 2 shows the descriptive sample statistics. All respondents answered the obligatory questions, and then the pedagogical questions, but the ones concerning technical presentation preparation were answered by $81 \%$ of examinees, as $19 \%$ do not use MM. According to age, participants were divided into five groups: $7.3 \%$ were young teachers up to 30 years old (27), $42.1 \%$ teachers from 30 to 40 years of age (155), 37.2\% teachers from 40 to 50 (137), $12.2 \%$ of teachers over 50 (45) and those over 60 accounted for $1.08 \%$, 
or 4 participants. In terms of types of educational institutions, 216 teachers were from primary schools, 101 from secondary vocational schools, and 51 from grammar schools.

The structure of participants according to the type of subject they teach is as follows: natural sciences -117 teachers $(31.79 \%)$, social sciences $-87(23.63 \%)$, technical and technological sciences - 130 (35.33\%), arts subjects $-23(6.25 \%)$, and physical education - 11 teachers (3\%).

Table 2

Descriptive Statistics

\begin{tabular}{|c|c|c|c|c|c|}
\hline & Tag & Min & Max & Mean & $\begin{array}{c}\text { Std. } \\
\text { Deviation }\end{array}$ \\
\hline Gender & Gen & 1 & 2 & 1,69 & 0,462 \\
\hline Age & At & 1 & 5 & 2,58 & 0,838 \\
\hline School & Sch & 1 & 3 & 1,55 & 0,725 \\
\hline Region & Reg & 1 & 3 & 1,24 & 0,599 \\
\hline Subject & $\mathrm{Sd}$ & 1 & 5 & 2,25 & 1,063 \\
\hline Computer in teaching & $\mathrm{Ct}$ & 1 & 5 & 3,53 & 1,239 \\
\hline $\begin{array}{l}\text { Do you use multimedia presentations as } \\
\text { a teaching resource? }\end{array}$ & $\mathrm{Mm}$ & 1 & 5 & 3,08 & 1,259 \\
\hline $\begin{array}{l}\text { How important to you personally are } \\
\text { presentations when teaching? }\end{array}$ & $\mathrm{EMP}_{1}$ & 1 & 3 & 2,21 & 0,518 \\
\hline MMP has a de-motivating effect on students. & $\mathrm{EMP}_{2}$ & 1 & 5 & 1,32 & 0,777 \\
\hline $\begin{array}{l}\text { MMP does not significantly affect motivation among stu- } \\
\text { dents, compared to traditional methods. }\end{array}$ & $\mathrm{EMP}_{3}$ & 1 & 5 & 2,05 & 1,122 \\
\hline $\begin{array}{l}\text { They may promote interest sometimes, if prepared in an } \\
\text { interesting way. }\end{array}$ & $\mathrm{EMP}_{4}$ & 1 & 5 & 3,71 & 1,126 \\
\hline It might affect motivation, but the teacher is the key figure. & $\mathrm{EMP}_{5}$ & 1 & 5 & 4,12 & 0,974 \\
\hline It greatly affects the motivation of students. & $\mathrm{EMP}_{6}$ & 1 & 5 & 3,85 & 0,996 \\
\hline Digital presentations do not increase teaching efficiency. & $\mathrm{EMP}_{7}$ & 1 & 5 & 1,59 & 1,022 \\
\hline It saves the teacher's time. & $\mathrm{EMP}_{8}$ & 1 & 5 & 3,57 & 1,168 \\
\hline Students are more motivated to follow the lecture. & $\mathrm{EMP}_{9}$ & 1 & 5 & 3,99 & 0,912 \\
\hline $\begin{array}{l}\text { Total student achievement is higher when presentations are } \\
\text { used. }\end{array}$ & $\mathrm{EMP}_{10}$ & 1 & 5 & 3,92 & 1,023 \\
\hline $\begin{array}{l}\text { As part of your schooling, did you attend subjects (courses) } \\
\text { that included contents related to the application of ICT in } \\
\text { teaching? }\end{array}$ & $\begin{array}{c}\mathrm{TE}_{1} \\
\left(\mathrm{Q} \_35\right)\end{array}$ & 1 & 2 & 1,64 & 0,481 \\
\hline $\begin{array}{l}\text { As part of your professional training, did you attend courses } \\
\text { that involved content related to the application of ICT in } \\
\text { teaching? }\end{array}$ & $\begin{array}{c}\mathrm{TE}_{2} \\
\left(\mathrm{Q} \_36\right)\end{array}$ & 1 & 2 & 1,33 & 0,470 \\
\hline \multicolumn{6}{|c|}{ Valid N (listwise): 368} \\
\hline
\end{tabular}

Table 2 shows the descriptive statistics of the basic factors and key groups regarding the efficiency of using multimedia presentations in the classroom. Pedagogical and other 
questions regarding the practice of preparing presentations are not shown in the table, owing to space constraints.

Correlation analysis MM on EMPi, $\mathrm{i}=1$ to 10 is shown in tables 3, 4, 5 and 6. The results refer to the sample of $\mathrm{N}=368$ participants, where Pearson correlation was used. Statistically significant correlations are highlighted in bold and marked as: ${ }^{*} p<0.05 ;{ }^{* *} p<0.01$.

Table 3

Pearson coefficients of the correlation between using multimedia presentations in the classroom, and teacher attitudes regarding presentation effectiveness (sample divided according to K1)

\begin{tabular}{|c|c|c|c|c|c|c|c|c|c|c|c|}
\hline Discipline (Sd) & & $E M P_{1}$ & $E M P_{2}$ & $E M P_{3}$ & $E M P_{4}$ & $E M P_{5}$ & $E M P_{6}$ & $E M P_{7}$ & $E M P_{8}$ & $E M P_{9}$ & $E M P_{10}$ \\
\hline $\begin{array}{l}\text { Natural } \\
\text { Sciences }\end{array}$ & & $0,225^{*}$ & $-0,093$ & $-0,077$ & 0,064 & 0,091 & 0,158 & 0,028 & $0,234^{*}$ & $0,340^{* *}$ & $0,273^{* *}$ \\
\hline Social Sciences & & $-0,015$ & $-0,175$ & $-0,102$ & $-0,157$ & 0,033 & $0,219^{*}$ & $-0,183$ & 0,086 & $0,324^{* *}$ & $0,235^{*}$ \\
\hline $\begin{array}{l}\text { Technical } \\
\text { Sciences }\end{array}$ & MM & $0,220^{*}$ & $-0,198^{*}$ & $-0,303^{* *}$ & 0,071 & $0,328^{* *}$ & $0,291^{* *}$ & $-0,479^{* *}$ & 0,166 & $0,475^{* *}$ & $0,407^{* *}$ \\
\hline Art subjects & & $-0,193$ & $-0,019$ & 0,031 & $-0,001$ & 0,179 & 0,392 & $-0,403$ & $0,443^{*}$ & $0,577^{* *}$ & $0,687^{* *}$ \\
\hline $\begin{array}{l}\text { Physical } \\
\text { Education }\end{array}$ & & $-0,250$ & 0,585 & 0,396 & 0,202 & 0,259 & 0,034 & 0,248 & 0,000 & 0,181 & $-0,139$ \\
\hline
\end{tabular}

Table 4

Pearson coefficients of the correlation between using multimedia presentations in the classroom

and teacher attitudes regarding the effectiveness of presentations in the classroom (sample divided according to K2)

\begin{tabular}{|c|c|c|c|c|c|c|c|c|c|c|c|}
\hline $\begin{array}{l}\text { Teacher } \\
\text { education }\end{array}$ & & $E M P_{1}$ & $E M P_{2}$ & $E M P_{3}$ & $E M P_{4}$ & $E M P_{5}$ & $E M P_{6}$ & $E M P_{7}$ & $E M P_{8}$ & $E M P_{9}$ & $E M P_{10}$ \\
\hline \multirow{2}{*}{$\mathrm{TE}_{1}$} & \multirow{3}{*}{ MM } & $234^{*}$ &,- 062 &,$- 176^{*}$ &,$- 177^{*}$ & ,034 & $264^{* * *}$ &,$- 350^{* *}$ & $221^{*}$ & $376^{* *}$ &, $337^{* *}$ \\
\hline & & ,080 &,- 095 &,- 087 & 108 & $263^{* *}$ &, $195^{* *}$ &,- 111 & $149^{*}$ &, $390^{* * *}$ &, $338^{* *}$ \\
\hline \multirow{2}{*}{$\mathrm{TE}_{2}$} & &, $162^{*}$ &,- 078 &,$- 164^{* *}$ &,- 109 &, 048 & $200^{* * *}$ &,$- 260^{* *}$ & ,089 & $288^{* * *}$ &, $319^{* * *}$ \\
\hline & $g_{4}$ & ,119 &,$- 192^{*}$ &,$- 193^{*}$ &, $213^{*}$ & ,308** &, $315^{* *}$ &,- 095 & $340^{* * *}$ & $449^{* * *}$ & $369^{* * *}$ \\
\hline
\end{tabular}

Table 5

Pearson coefficients of the correlation between using multimedia presentations and teacher attitudes regarding the effectiveness of presentations in the classroom (sample divided according to K3)

\begin{tabular}{|c|c|c|c|c|c|c|c|c|c|c|c|}
\hline Age & & $E M P_{1}$ & $E M P_{2}$ & $E M P_{3}$ & $E M P_{4}$ & $E M P_{5}$ & $E M P_{6}$ & $E M P_{7}$ & $E M P_{8}$ & $E M P_{9}$ & $E M P_{10}$ \\
\hline $20-30$ & $\mathrm{MM}$ & $-0,014$ & $-0,142$ & $-0,316$ & $-0,215$ & 0,004 & $0,524^{* *}$ & $-0,384^{*}$ & 0,231 & $0,544^{* *}$ & $0,482^{*}$ \\
\hline $31-40$ & & $0,287^{* *}$ & $-0,076$ & $-0,025$ & 0,133 & $0,260^{* *}$ & $0,232^{* *}$ & $-0,164^{*}$ & $0,200^{*}$ & $0,447^{* *}$ & $0,356^{* *}$ \\
\hline $41-50$ & & 0,119 & $-0,105$ & $-0,146$ & 0,011 & $0,300^{* *}$ & $0,220^{* *}$ & $-0,245^{* *}$ & 0 & $0,358^{* *}$ & $0,370^{* *}$ \\
\hline $51-60$ & & 0,188 & $-0,005$ & $-0,279$ & $-0,147$ & $-0,124$ & 0,270 & $-0,251$ & $0,301^{*}$ & $0,343^{*}$ & $0,384^{* * *}$ \\
\hline $60+$ & & 0,000 & $-0,943$ & $-0,749$ & $-0,985^{*}$ & $-0,183$ & 0,000 & $-0,471$ & 0,187 & 0,739 & 0,471 \\
\hline
\end{tabular}

Table 6

Pearson coefficients of the correlation between using multimedia presentations and teacher attitudes regarding the effectiveness of presentations in the classroom (sample divided according to K4)

\begin{tabular}{lcccccccccc}
\hline Gender & $E M P_{1}$ & $E M P_{2}$ & $E M P_{3}$ & $E M P_{4}$ & $E M P_{5}$ & $E M P_{6}$ & $E M P_{7}$ & $E M P_{8}$ & $E M P_{9}$ & $E M P_{10}$ \\
\hline Male & 0,104 & $-0,020$ & 0,006 & 0,084 & $0,348^{* *}$ & 0,117 & 0,121 & 0,138 & $0,386^{* *}$ & 0,184 \\
Female & $0,191^{* *}$ & $0,157^{*}$ & $0,180^{* * *}$ & $-0,013$ & 0,109 & $0,312^{* * *}$ & $0,252^{* *}$ & $0,226^{* *}$ & $0,417^{* *}$ & $0,452^{* * *}$ \\
\hline
\end{tabular}




\section{Discussion}

The descriptive statistics arrived at certain parameters of common practice for teachers designing and implementing multimedia presentations. Participants first answered a group of pedagogical and didactic questions $\left(\mathrm{PQ}_{\mathrm{i}}\right)$. The description shows that $19 \%$ of them never use multimedia presentations in teaching, $9 \%$ use them only rarely, $26.9 \%$ sometimes, $35.6 \%$ often, and $9.5 \%$ always. Exceptions to the interpretation of the given results concern the problem of the limitations of the interpretation and use of the results: the research is based on the estimations of the respondents themselves, namely by using questionnaires.

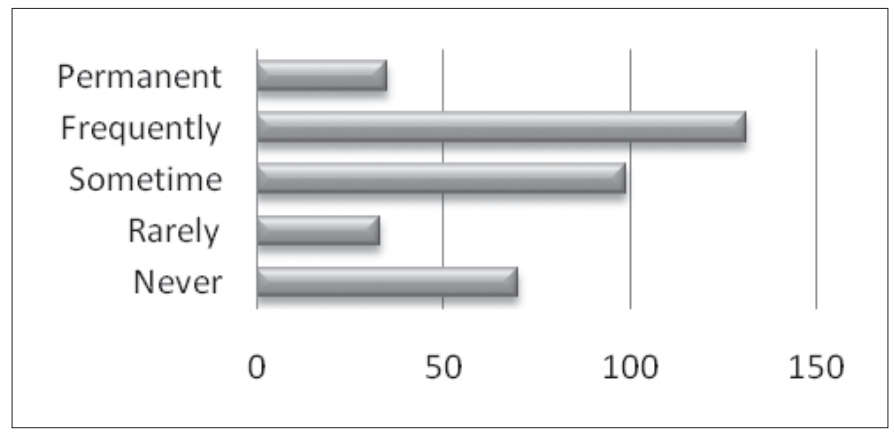

Figure 1 Frequency of use for MM presentations among participants

Among those who implement multimedia presentations in the classroom, those who use them when introducing new material in a lesson represent the majority, as high as $94 \%$, with a gradation of "sometimes, often, always", up to two times per month $-38.8 \%$, between three and five times $-36.4 \%$, and more than five times $-24.8 \%$. When the lesson involves practice, $76.4 \%$ use them. When it comes to evaluating lessons, the highest number (28.9\%) is for those who answered that they use presentations "sometimes". On questions that differentiate between the use of presentations in the introductory, main, or concluding part of lessons, the highest percentage answered that they use them in the main part of lessons, specifically $94.6 \%$ of respondees.

The next group of questions from the questionnaire researched common practices among teachers when creating multimedia presentations $\left(\mathrm{DMP}_{\mathrm{i}}\right)$. Not surprisingly, the answer to the question of who creates their presentations is that $71.7 \%$ create presentations entirely independently, $19.7 \%$ in collaboration with their colleagues, while $8.6 \%$ stated that presentations are created by a third party. Regarding the time spent on creating a presentation, $53.2 \%$ said they spend on average between an hour and 2 hours, $17.6 \%$ of them are faster and do it in less than an hour, and $29.1 \%$ of teachers who make presentations on their own spend more than two hours on each. Perhaps this is one of the reasons for the structure of answers to the question of whether they would be more inclined to use presentations in the teaching process if they received them ready-prepared from the relevant institutions: only $8.3 \%$ of them answered that it would make no difference, while $43.6 \%$ answered "Maybe", and $48.1 \%$ of them said that they would greatly appreciate and make use of this resource. 
Further on in the questionnaire, there were questions exclusively related to the technical aspects of creating presentations. $46.1 \%$ of teachers often or always create a pre-scenario for the presentation, while $35.3 \%$ answered that they rarely do so. Multimedia elements that teachers include in a multimedia presentation are (often or always): text $87.3 \%$; image $93.6 \%$; sound $45.9 \%$; animation $62.2 \%$; video $53.1 \%$, and simulation $27.3 \%$. As sources for multimedia texts, teachers mostly use internet resources and textbooks. They use the internet most often for images, as many as $72 \%$. As for the average number of slides in their presentations, a statistically insignificant number contains up to 3 slides, $25.7 \%$ feature between 4 and 7 slides, and $73.2 \%$ consist of over 7 slides. Teachers usually draw on theory for $78.8 \%$ of a presentation, yet feature whole sentences in $20.5 \%$ of cases. $64.8 \%$, which is to say the majority, mainly use a font size between 12 and 18 pt. Black is the least-used colour for text, accounting for just $4.9 \%$, followed by blue at $29 \%$, while $66.1 \%$ answered that they employ a variety of colours for text. For the background, $41.3 \%$ of them use ready-made templates, $47 \%$ create their own, and $11.7 \%$ of teachers leave the background white. Effects in presentations are not particularly popular, and only one third claimed to use special effects in presentations.

Table 3 presents Pearson correlation coefficients between the use of multimedia presentations in the classroom and teacher attitudes regarding presentation effectiveness, this within a differentiated sample according to the teacher's subject type. We can see that teachers of natural sciences and technical subjects gave answers that point to a nearly identical, strong, positive correlation between the use of presentations, with the statement that when teaching they rely to some extent on presentations $\left(\mathrm{EMP}_{1}\right)$. In addition, teachers of natural science subjects also demonstrate the attitude that a presentation saves time writing content on the board $\left(\mathrm{EMP}_{8}\right)$, which was not a criterion for teachers of technical sciences. Social sciences teachers, who use presentations in the classroom but do not rely on them too much during their lessons, nevertheless state that they greatly affect the motivation of students $\left(\mathrm{EMP}_{6}\right)$. Teachers of technical subjects gave answers that showed strongly negative attitudes towards the statement that MMP is de-motivating for students, and that it does not significantly alter student motivation in comparison to the traditional method, which is not true for teachers in all other categories. Also, teachers from this category think that MMP might affect motivation, but hold that the teacher is the key figure $\left(\mathrm{EMP}_{5}\right)$. They are very much against the statement that digital presentations do not increase the efficiency of teaching $\left(\mathrm{EMP}_{7}\right)$, whereas none of the other categories of teachers were significantly opposed. The most interesting finding in this part of the research is that in the replies of four categories of teachers (natural sciences, social sciences, technical and arts subjects) there is a strong, positive correlation between the use of presentations, with statements that students are more motivated to follow the lecture $\left(\mathrm{EMP}_{9}\right)$, and that student achievement is improved when presentations are used $\left(\mathrm{EMP}_{10}\right)$. For the last statement, regarding performance in terms of overall student achievement, and according to intensity of correlation, art teachers were in first place, closely followed by teachers of technical subjects. We can conclude that teacher attitudes vary regarding the importance and effectiveness of applying multimedia presentations with regard to student achievement, depending on the type of subjects taught, which proves hypothesis $h 1$. 
Table 4 shows Pearson coefficients of the correlation between using multimedia presentations in the classroom and teacher attitudes regarding presentation effectiveness in the classroom, within a differentiated sample according to the type of education teachers have had (SDi) in terms of applying ICT in the classroom. With regard to the means of acquiring competencies for the use of ICT in teaching we posed two separate questions. The first concerned the formal education of teachers and thereby the acquired competences for the use of computers in teaching. 133 of the total number of participants answered that they had learned skills in this way, which amounts to $36.14 \%$, while 235 of them stated that their competencies were not gained in this way. The second question related to the competencies that teachers had acquired through non-formal education, by way of professional development programmes. Most answered that they had received instruction in this way -247 or $67.12 \%$ of the total number of participants, while 121 teachers had not. We can observe significant correlations between groups that were educated formally (g1) and informally (g3), and their attitudes towards efficiency. Teachers from both groups ( $\mathrm{g} 1$ and g3) have almost equally significant correlations for using presentations when it comes to questions $\mathrm{EMP}_{1^{\prime}} \mathrm{EMP}_{3^{\prime}} \mathrm{EMP}_{4^{\prime}} \mathrm{EMP}_{6}$ and $\mathrm{EMP}_{7}$. We conclude from this that they have the same positive attitude towards the role of multimedia presentations in teaching and feel that motivation among students is heightened through their use. Both groups of teachers, even those from g2 and g4 expressed a strong belief that students are more motivated to follow the lecture, and that overall student achievement is better with the use of presentations $\left(\mathrm{EMP}_{9}\right.$ and $\left.\mathrm{EMP}_{10}\right)$. Where the attitudes of the two groups of teachers differ significantly is in their attitude towards MMP with regard to the possibility of saving the teacher's time, which is where members of $\mathrm{g} 1$ display a positive attitude, and members of $\mathrm{g} 3$ display a negative attitude. This indicates that the difference between formal and non-formal teacher training is not a significant factor leading to a difference in attitudes regarding the effectiveness of using multimedia presentations in the classroom, by which hypothesis $\mathrm{h} 2$ is disproved.

Table 5 presents the correlative relationship between the use of multimedia presentations in the classroom and teacher attitudes regarding the effectiveness of using presentations in the classroom within the differentiated sample according to age. For question $\mathrm{EMP}_{9}$, all correlation coefficients are positive and significant, except for age 60+, which is not significant but represents the main difference. In addition, it is interesting that the youngest group of participants views the relationship as more significant, but that as the age of respondees increases, the importance ascribed is seen to decline (up to age $60+$, where there is no significance). From $50-60$ years of age, the significance is $p<0.05$, while for the younger groups it is $<0.01$ - which is also the difference in addition to the amount of the correlation. For EMP ${ }_{10}$ all correlation coefficients are also positive and significant, just with a smaller difference between them. This proves hypothesis $\mathrm{h} 3$ that the importance of different views on the effectiveness of using multimedia presentations means that perceptions of overall student achievement vary according to teacher age. This is in accordance with Tezci's finding (2009). He found through studies conducted in Turkish schools that attitudes among teachers towards computers and the internet vary in line with years of experience and levels of knowledge. 
Table 6 shows the correlative relationship between the use of multimedia presentations in the classroom and teacher attitudes regarding the effectiveness of using presentations in class, within the sample differentiated according to gender. Teachers of both genders have almost equally significant correlations only for the $\mathrm{EMP}_{4}$ issue. In the group of female respondents, a more significant level of correlation is noted between the use of multimedia presentations in teaching and attitudes $\mathrm{EMP}_{1^{\prime}} \mathrm{EMP}_{3^{\prime}} \mathrm{EMP}_{6^{\prime}} \mathrm{EMP}_{7^{\prime}} \mathrm{EMP}_{8^{\prime}}$ and a particularly strong correlation with issues $\mathrm{EMP}_{9}$ and $\mathrm{EMP}_{10}$. Both male and female teachers who use presentations in teaching feel that students are more motivated to follow the class, but only female teachers feel that overall student achievement is improved with their use $\left(\mathrm{EMP}_{10}\right)$. It is interesting that male teachers feel that the teacher is still the key figure in the class, and that they attach great importance to this, while female teachers do not $\left(\mathrm{EMP}_{5}\right)$. From this result we can conclude that hypothesis 4 has been proved, namely that the importance of teachers' views on the effectiveness of applying multimedia presentations is such that perceptions of overall student achievement vary according to teacher gender.

This finding is somewhat surprising, because in the authors' view a common perception has arisen that men are somehow more inclined to use computers in the teaching process. This may represent a correlation with two dimensions. It is evident that male teachers feel that computers are important, and yet they see no significant connection between this and overall achievement in the classroom. Rather, they view the teacher as the paramount factor. This may reflect a higher level of confidence on the part of male teachers, and a greater conviction that the teacher is the key and central figure in the learning process. Meelissen and Drent (2008) reported similar findings in their research. They found that in the Netherlands female teachers demonstrated a more positive attitude towards computer use than their male counterparts. We should also mention results obtained by Crump \& Logan (2007). They researched the behaviour of women employed in the ICT industry and found that they perceived their gendered roles to be a highly important and integral part of ICT, and that they were very willing to adapt to change and advance.

\section{Conclusion}

Some of the research findings are especially useful. Firstly, this research has determined the structure behind the means of creating and applying multimedia presentations in teaching in Serbian schools. One significant finding from this research is that multimedia presentations are never used by $19 \%$ of respondents, but that $81 \%$ of teachers in Serbian schools do use multimedia presentations in the classroom. What is also in evidence from the results is that the methods used in creating presentations are far from uniform.

Initial hypotheses h1, h3 and h4 have been proven, so we can say that the importance of attitudes regarding the effectiveness of applying multimedia presentations on student achievement varies depending on the type of subjects taught, and the age and gender of teachers. Initial hypothesis h2 has not been proven, and we cannot claim with certainty that the kind of training through which teachers gain competence in applying ICT in the classroom affects attitudes regarding the importance and effectiveness of using multimedia presentations where overall student achievement is concerned. 
In accordance with these findings, conclusions were drawn regarding measures that should be implemented in educational strategy, and these provide for the planning of a guidance framework for courses involving multimedia in teacher education curricula within all fields as a compulsory subject. This suggestion stems from the fact that teachers, through vocational and professional training programmes, are able to skip certain seminar topics, and so the programme regarding the pedagogical integration of multimedia in teaching might be bypassed entirely. In this way, teachers of all subjects would prepare adequately for the implementation of multimedia methods. This view is in accordance with the attitude of Nelson (2014): "Technology impacts teacher education that has been mandated to incorporate the knowledge of various methods for today's classrooms. Trainings to be sufficiently flexible to encourage pre-service teachers to use the available technology in their delivery of subject content." This accords with a recommendation from Shaing Kwei et al. from 2014, which describes the idea that design principles are essential for future professional development programmes aimed at preparing teachers to adopt a cognitive tools approach.

Another suggestion stemming from the research results is that in the domain of non-formal education for teachers, the structure of mandatory seminars, which would include some related to multimedia, ought to be defined. That is definitely an area that must be included in Long Life Learning frameworks, with a set time limit in which this competence must be renewed. This is in agreement with Rienties \& Kinchin (2014), who arrived at conclusions in the course of their studies that indicate research on the impact of teacher education should widen its scope beyond formal programme boundaries. According to Lauer et al. (2014), design features associated with the positive impacts of short-term professional development include sufficient time spent on topic complexity, the use of learning objectives, alignment with participants' training needs, demonstrations of desired behaviours, opportunities for participant practice, group discussions, pre-work and homework, active learning tasks that require cognitive processing, and a participant-centred setting and follow-up support to promote the transfer of learning. Also, one of the suggestions is to broaden the mechanisms of advisability and supervision in the field of making independent presentations at the level of school administration.

The third suggestion is in accordance with the cloud computing paradigm, which Buyya et al. (2009) claim will provide the basic level of computing service considered essential for meeting the everyday needs of the general community. We must not ignore the findings of the research, according to which $91.7 \%$ of teachers expressed a greater inclination to use presentations in the teaching process if these are received ready prepared from the competent authorities. The suggestion is to form a national cloud repository of multimedia presentations according to subjects and grades, by means of which teachers could access and download ready-made licensed presentations, which would help them in terms of their existing lack of time and other resources. But in doing so, leave the teacher enough room to express their own creative ideas and individual skills. According to Aaron \& Roche (2012), cloud computing refers to the use of computing resources on the internet instead of on individual personal computers, and has significant potential value for educators. Chandra (2012) noted the benefit of using cloud computing for educational institutions in order to deliver better services with even fewer resources. Among other factors, he stated that this would lead to an exponential increase in the number of users taking advantage of online educational resources. 


\section{References}

Aaron, L. S., \& Roche, C. M. (2011). Teaching, learning, and collaborating in the cloud: applications of cloud computing for educators in post-secondary institutions. Journal of Educational Technology Systems, 40(2), 95-111.

Atkins, M. J. (1993). Theories of learning and multimedia applications: an overview. Research Papers in Education, 8(2), 251-271.

Bennett, S., \& Maton, K. (2010). Beyond the 'digital natives' debate: Towards a more nuanced understanding of students' technology experiences. Journal of computer assisted learning, 26(5), $321-331$.

Berk, R. A. (2011). Research on PowerPoint ${ }^{\oplus}$ : From basic features to multimedia. International Journal of Technology in Teaching and Learning, 7(1), 24-35.

Buyya, R., Yeo, C. S., Venugopal, S., Broberg, J., \& Brandic, I. (2009). Cloud computing and emerging IT platforms: Vision, hype, and reality for delivering computing as the 5 th utility. Future Generation computer systems, 25(6), 599-616.

Chandra, D. G., \& Borah, M. D. (2012). Cost benefit analysis of cloud computing in education. In Computing, Communication and Applications (ICCCA), 2012 International Conference on (pp. 1-6). IEEE.

Chien, Y. T., Chang, C. Y., Yeh, T. K., \& Chang, K. E. (2012). Engaging pre-service science teachers to act as active designers of technology integration: A MAGDAIRE framework. Teaching and Teacher Education, 28(4), 578-588.

Chuang, H. H., \& Liu, H. C. (2012). Effects of different multimedia presentations on viewers' informationprocessing activities measured by eye-tracking technology. Journal of Science Education and Technology, 21(2), 276-286.

Craig, R. J., \& Amernic, J. H. (2006). PowerPoint presentation technology and the dynamics of teaching. Innovative Higher Education, 31(3), 147-160.

Crump, B. J., Logan, K. A., \& Mcllroy, A. (2007). Does gender still matter? A study of the views of women in the ICT industry in New Zealand. Gender, Work \& Organization, 14(4), 349-370.

Ertmer, P. A., \& Ottenbreit-Leftwich, A.T. (2010). Teacher technology change: How knowledge, confidence, beliefs, and culture intersect. Journal of research on Technology in Education, 42(3), 255-284.

Jimoyiannis, A., \& Komis, V. (2007). Examining teachers' beliefs about ICT in education: Implications of a teacher preparation programme. Teacher development, 11(2), 149-173.

Hashemi, M., Azizinezhad, M., \& Farokhi, M. (2012). Power Point as an innovative tool for teaching and learning in modern classes. Procedia-Social and Behavioral Sciences, 31, 559-563.

Kirschner, F., Kester, L., \& Corbalan, G. (2011). Cognitive load theory and multimedia learning, task characteristics and learning engagement: The current state of the art. Computers in Human Behavior, 27(1), 1-4

Lachs, V. (2013). Making Multimedia in the Classroom: A Teachers' Guide. London and New York: Routledge.

Lauer, P. A., Christopher, D. E., Firpo-Triplett, R., \& Buchting, F. (2014). The impact of short-term professional development on participant outcomes: a review of the literature. Professional Development in Education, 40(2), 207-227.

Le Fevre, D. M. (2014). Barriers to implementing pedagogical change: The role of teachers' perceptions of risk. Teaching and Teacher Education, 38, 56-64. 
Liang, Y., Zhang, J., \& Li, X. (2010, August). Theories of Selective Attention and Presentation of Teaching Information in Multimedia-Based English Class. In Management and Service Science (MASS), 2010 International Conference (pp. 1-3). IEEE.

Liaw, S. S., Huang, H. M., \& Chen, G. D. (2007). Surveying instructor and learner attitudes toward multimedia. Computers \& Education, 49(4), 1066-1080.

Meelissen, M. R., \& Drent, M. (2008). Gender differences in computer attitudes: Does the school matter?. Computers in Human behavior, 24(3), 969-985.

Nelson, D. F. (2014). PowerPoint use in undergraduate teacher education classes: Perspectives of lementary and secondary pre-service teachers (Doctoral dissertation). University of Alberta.

Prabhakaran, B. (2000). Adaptive multimedia presentation strategies. Multimedia Tools and Applications, 12(2-3), 281-298.

Rienties, B., \& Kinchin, I. (2014). Understanding (in) formal learning in an academic development programme: A social network perspective. Teaching and Teacher Education, 39, 123-135.

Sikos, L., Varbanov, T. K. P., \& Lam, H. L. (2009). The role of structured multimedia to improve the teaching impact in process integration. Chemical engineering, 18, 767-772.

Simpson, C. L., Pollacia, L., Speers, J., \& Willis, H. (2014). An analysis of certain factors related to the use of PowerPoint. Communications of the IIMA, 3(2), 4.

Teo, T. (2009). Modelling technology acceptance in education: A study of pre-service teachers. Computers \& Education, 52(2), 302-312.

Teo, T., Ursavas, Ö. F., \& Bahçekapili, E. (2011). Efficiency of the technology acceptance model to explain pre-service teachers' intention to use technology: a Turkish study. Campus-Wide Information Systems, 28(2), 93-101.

Tezci, E. (2009). Teachers' effect on ICT use in education: The Turkey sample. Procedia-Social and Behavioral Sciences, 1(1), 1285-1294.

Wang, S. K., Hsu, H. Y., Campbell, T., Coster, D. C., \& Longhurst, M. (2014). An investigation of middle school science teachers and students use of technology inside and outside of classrooms: considering whether digital natives are more technology savvy than their teachers. Educational Technology Research and Development, 1-26.

Yang, F. Y., Chang, C. Y., Chien, W. R., Chien, Y. T., \& Tseng, Y. H. (2013). Tracking learners' visual attention during a multimedia presentation in a real classroom. Computers \& Education, 62, 208-220.

Примљено: 03. 12. 2018. 


\title{
Педагошки аспекти коришћења мултимедијалних презентација у учионици - студија случаја, Србија
}

\author{
Иван Тасић \\ Катедра за методике наука и технологије у образовању, \\ Технички факултет „Михајло Пупин“, Универзитет у Новом Саду, \\ Зрењанин, Србија \\ Драгана Глушац \\ Катедра за методике наука и технологије у образовању, \\ Технички факултет „Михајло Пупин“, Универзитет у Новом Саду, \\ Зрењанин, Србија \\ Дијана Каруовић \\ Катедра за методике наука и технологије у образовању, \\ Технички факултет „Михајло Пупин“, Универзитет у Новом Саду, \\ Зрењанин, Србија
}

\begin{abstract}
Айсйракй

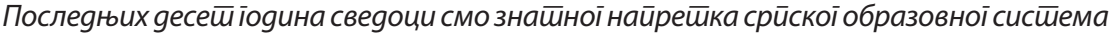

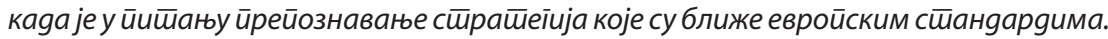

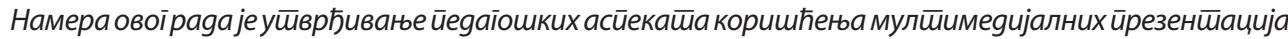
у учионицама у Србији, као и факйора који ушиичу на моїуће разлике у мишљенима насйавника

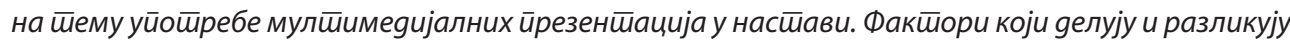

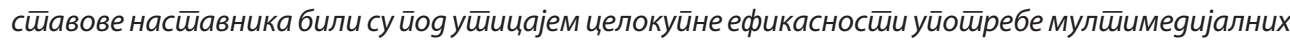
йрезенйација које уйичу на укуйна йосӣиїнућа ученика. Узели смо у обзир ниво обуке међу

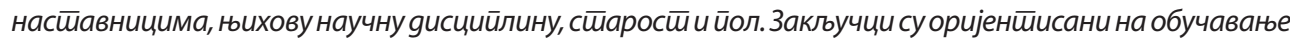

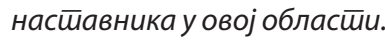

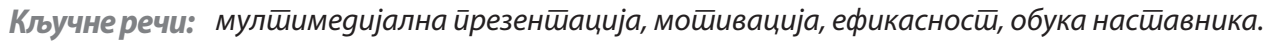




\title{
Педагогические аспекты использования мультимедийных презентаций в классе - на примере Сербии
}

\author{
Иван Тасич \\ Кафедра методики науки и технологий в образовании, \\ Технический факультет «Михайло Пупин», Университет в Нови-Саде, \\ Зренянин, Сербия \\ Драгана Глушац \\ Кафедра методики науки и технологий в образовании, \\ Технический факультет «Михайло Пупин», Университет в Нови-Саде, \\ Зренянин, Сербия \\ Дияна Каруович \\ Кафедра методики науки и технологий в образовании, \\ Технический факультет «Михайло Пупин», Университет в Нови-Саде, \\ Зренянин, Сербия
}

\begin{abstract}
Резюме За послеgние десять лет являемся свидетелями значительного прогресса в сербской системе образования, когда речь идет о выявлении стратегий, более близких к европейским стандартам. Цель данной работы заключается в определении педагогических аспектов использования мультимедийных презентачий в классе в Сербии, а также факторов, которые влияют на возможные различия во взглядахучителей на использование мультимедийных презентаций в обучении. Факторы, определяющие и дифференцирующие отношения учителей, находятся под воздействием всеобщей эффективности использования мультимедийных презентаций, которые влияют на общие достижения учащихся. Исследователи приняли во вниманиеуровень подготовки, научную дисциплину, возраст и получителей. Выводы ориентированы на подготовку учителей в этой области.
\end{abstract}

Ключевые слова: мультимедийная презентация, мотивачия, эффективность, подготовка учителей. 